\title{
Wojna z niewiernymi w opinii chrześcijańskiego Zachodu
}

Jerzy Strzelczyk 


\section{Jerzy Strzelczyk}

\section{Wojna $z$ niewiernymi \\ w opinii chrześcijańskiego Zachodu}

1.

ie później niż w maju 1136 roku opublikował Bernard z Clairvaux, już wówczas wybitna
postać zachodniego Kościoła, właściwy twórca potężnego i błyskawicznie rozprzestrzeniającego się w Europie zakonu cystersów, traktat De laudae novae militiae ${ }^{1}$. Bezpośrednim adresatem traktatu był krewny Bernarda, pierwszy wielki mistrz templariuszy, Hugon de Payns; do templariuszy, ale także do całego świata chrześcijańskiego skierowana była jego treść.

Jest to apologia nowego zjawiska, jakim w tym świecie od niedawna były zakony rycerskie, zwłaszcza templariusze, milites Templi, powstałe w Ziemi Świętej, opanowanej na przełomie XI i XII wieku, w rezultacie I krucjaty, przez krzyżowców ${ }^{2}$. Nie był to problem jedynie akademickiej natury. Podobnie jak same wyprawy krzyżowe - będzie o tym jeszcze mowa — od początku budziły tu i ówdzie w świecie chrześcijańskim zasadnicze wątpliwości, co prawda przytłumione spektakularnym sukcesem pierwszej z nich (ożywią się wraz z kolejnymi niepowodzeniami i klęskami poczynając od lat czterdziestych XII wieku) oraz prokrucjatową propagandą papiestwa i propapieskich zakonów; podobnie ostrą krytykę, zwłaszcza w ustabilizowanych kręgach mona-

\footnotetext{
1 Wyd. J. Leclercq, H. M. Rochais w: Sancti Bernardi opera, t. 3, Romae 1963, s. 213 i n. Zob. J. Fleckenstein, Die Rechtfertigung der geistlichen Ritterorden nach der Schrift „De laude novae militiae” Bermhards von Clairvaux, w: Die geistlichen Ritterorden Europas, red. J. Fleckenstein, M. Hellmann, Sigmaringen 1980 (Vorträge und Forschungen, hg. vom Konstanzer Arbeitskreis für mittelalterliche Geschichte, Bd. 26), s. 9-22.

${ }^{2} \mathrm{O}$ templariuszach $w$ języku polskim, pomijając prace o charakterze ogólnym, dotyczące dziejów chrześcijaństwa, monastycyzmu i wypraw krzyżowych (a także szczególnie tą problematyką zainteresowaną literaturç paranaukową) por. M. Mclville, Dzieje templariuszy, tł. A. Jędrychowska, Warszawa 1991; M. Barber, Templariusze, tt. R. Sudół, Warszawa 1999. O templariuszach w Polsce ostatnio, $z$ uwzględnieniem całego dotychczasowego dorobku badań: M. Starnawska, Między Jerozolimq a Eukowem. Zakony krzyżowe na ziemiach polskich w średniowieczu, Warszawa 1999, rozdz. 2.
} 
stycznych, wywoływał eksperyment polegający na powiązaniu ideałów monastycznych i rycerskich w postaci zakonów rycerskich. Wiadomo, że początki zakonu templariuszy ${ }^{3}$, mimo poparcia ze strony króla jerozolimskiego Baldwina II, były trudne i rychło doszło do fazy stagnacji. O przezwyciężenie tego stanu rzeczy chodziło wielkiemu cystersowi. Przeciwstawił on templariuszy, ów nieznany czasom wcześniejszym novum militiae genus, powstały niedawno - bez wątpienia nieprzypadkowo - w tej części świata, w której niegdyś Światłość Wiekuista przybrała postać ludzka w celu wypędzenia Księcia Ciemności. To awangarda zbawienia (cornu salutis) w domu Dawida. Nowy zakon odróżnia się od wszelkich innych prowadzeniem podwójnej walki, jednej - natury doczesnej, drugiej — duchowej, walczy równocześnie z ludzkimi przeciwnikami i demonami, spełnia zatem zadania zarezerwowane dotąd dla dwóch grup: rycerstwa i mnichów. Rycerz Chrystusowy, nawet gdy padnie w bitwie, pozostaje zwycięzcą, gdyż może być pewny Królestwa Niebieskiego. Gdy zwycięża i zabija, służy Chrystusowi, gdy sam polegnie w boju, przysługuje się sobie samemu:

Securi ergo procedite, milites - zwraca się Bernard do rycerzy-zakonników - et intrepido animo inimicos crucis Christi propellite, certi quia neque mors, neque vita poterunt vos separare a caritate Dei.

Templariuszom, militibus Templi, „rycerzom Chrystusa”, przeciwstawia Bernard w niesłychanie gwałtowny sposób „zwykłe”, świeckie rycerstwo, przedstawione w niezwykle czarnych barwach. Militia saecularis jest pełna wad i grzechu, to raczej „malitia” niż „militia”. Należący do niej rycerze dbaja jedynie o dobra doczesne, są pyszni, okrywają rumaki paradnymi, jedwabnymi tkaninami, własne zbroje także zdobią kosztownymi materiałami, malują włócznie, tarcze i siodła, zdobią cugle i strzemiona złotem, srebrem i szlachetnymi kamieniami - wszystkie te „niewieście błyskotki" (muliebria ornamenta), z którymi rycerzowi wypadnie spotkać śmierć, to zwykła próżność, podobnie jak długie, kunsztownie trefione włosy, modne, długie szaty, długie rękawice, w gruncie rzeczy raczej przeszkadzające w rycerskim dziele. Rycerz potrzebuje jedynie trzech rzeczy: musi być dzielny, aby się obronić, zręcznie się poruszać i być zdolny do natarcia. Tymczasem oni wcale nie chcą się tym zadowolić, uprawiają różne, często niebezpieczne, na pewno zaś zbędne praktyki, prowadzą (niesprawiedliwe) wojny, wywołują zatargi, powodują się gniewem, zazdrością i chciwością na dobra doczesne, grają w szachy i kości, polują, śpiewają, słuchają bajarzy (fabulatores), lubują się w ludorum spectacula, oddają się turniejom.

Co innego templariusze: rezygnują z wszelkiego blichtru, żyją w pełnym blasku zasad ewangelicznych, przede wszystkim miłości, ubóstwa, posłuszeństwa i czystości, dążą jedynie do jak najlepszego spełnienia swego posłannictwa — do zwycięstwa nad nieprzyjacielem. Prawda, że jest ich niewielu, zaledwie garstka, paucos admodum in tanta multitudine hominum, ale już są straszni muzułmanom.

Co mogli odczuwać ówcześni przedstawiciele „zwykłego” rycerstwa, zakładając, że znana im byłaby bulwersująca treść omawianego pisma Bernarda z Clairvaux? Na pewno ogromny dys-

${ }^{3}$ Zob. M. Melville, Les Debuts de l'Ordre du Temple, w: Die geistlichen Ritterorden..., op. cit., s. 23-30. 
komfort psychiczny i rozczarowanie. Zauważmy, że aczkolwiek już od kilkudziesięciu lat, to znaczy od pierwszej, zwycięskiej przecież, wyprawy krzyżowej pod sam koniec XI stulecia, termin "milites Christi” znalazł, nawet w oficjalnych wypowiedziach Kościoła, zastosowanie w odniesieniu do krzyżowców (i sam Bernard gdzie indziej w tym szerszym znaczeniu go niejednokrotnie stosuje), w De laude novae militiae mowa nie o krzyżowcach w ogóle, lecz jedynie o nikłej ich części — tej, która nie powróciła do domu, ani nawet nie osiadła w Ziemi Świętej, wiodąc w przybliżeniu taki sam, choćby w bardziej eksponowanej pozycji, tryb życia jak uprzednio, lecz wybrała trudny i nadzwyczaj niebezpieczny los „wiecznych krzyżowców”.

Nie ulega wątpliwości, że powstanie i wczesna działalność zakonów rycerskich w Ziemi Świętej budziły bynajmniej nieodosobnione wątpliwości i zastrzeżenia fundamentalnej natury. Wychodziły one najczęściej ze sfer monastycznych. Prawdą jest, na co dobitnie zwrócił uwagę Josef Fleckenstein ${ }^{4}$, że choć w świadomości ludzi ówczesnych, przywykłych postrzegać społeczeństwo w kategoriach sztywnego funkcjonalnego schematu stanowego: duchowieństwo (oratores), rycerstwo (bellatores), chłopi (laboratores) ${ }^{5}$, i z założenia niejako niechętnych innowacjom, rycerstwo (czy szerzej: życie światowe) i życie zakonne jawiło się na ogół w ostrej wzajemnej opozycji, w okresie rozwiniętego średniowiecza, już przed Bernardem z Clairvaux, trwał jednak proces zbliżania się monastycyzmu i rycerstwa, wzajemnego otwierania się. Przejawami tego była z jednej strony dywersyfikacja, poczynając od drugiej połowy XI wieku, samego ruchu monastycznego, w którym monastycyzm benedyktyński, od czasów karolińskich bezwzględnie dominujący na Zachodzie, stawał się tylko jednym nurtem, w dodatku nie najbardziej dynamicznym, a coraz większe znaczenie zyskiwały nurty nowe, bardzo między sobą, jak również od tradycyjnego benedyktynizmu różniące się. Do głosu dochodziły przeciwstawne sobie tendencje, z których jedna polegała na intensyfikacji wewnętrznych przeżyć religijnych i nie musiała od razu, tak jak na przykład u cystersów wczesnej doby, prowadzić do zmasowanego otwarcia na świat zewnętrzny, ale w miarę upływu czasu procesowi takiego otwarcia nolens volens ulegała, druga zaś niejako programowo ku temu zewnętrznemu światu otwierała się poprzez działalność duszpasterską, kaznodziejską, misyjną, charytatywną, szpitalniczą, opiekuńczą (na przykład w stosunku do pielgrzymów czy w postaci wykupywania jeńców), wreszcie zwykłą aktywność gospodarczą. Z drugiej strony ideologia chrześcijańska i przejęcie się przez ludzi Kościoła, zwłaszcza papiestwo i biskupów, co najmniej od czasów karolińskich, sprawami państwa i społeczeństwa, prowadziły stopniowo do przemian w tym, co można i należałoby określić jako etos rycerski, przede wszystkim

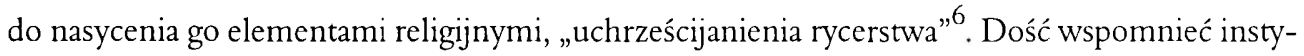

${ }^{4}$ Zob. J. Fleckenstein, op. cit.

${ }^{5}$ Zob. J. Le Goff, Note sur société tripartie, idéologie monarchique et renouveau écononique dans la Chrétienté du IX $X^{t}$ au XII s., w: L'Europe aux $I X^{e}-X I^{e}$ siècles. Aux origines des Etats nationaux, red. T. Mantcuffel, A. Gieysztor, Varsovic 1968, s. 63-71 (dyskusja na s. 72-74); O. G. Ocxlc, Die funktionale Dreiteilung der Gesellschaft bei Adalbero von Laon. Deuttungsschemata der sozialen Wirklichkeit im frühen Mittelalter, „Frühmittclalterliche Studien” 12, 1978, s. 1 i n.; G. Duby, Les trois Ordres ou l'imaginaire du féodalisme, Paris 1979.

${ }^{6}$ Zob. R. Barber, Rycerze i rycerskoš́, tt. J. Kozłowski, Warszawa 2000, a jeżcli chodzi o stosunki w naszcj czçści Europy: Etos rycerski w Europie Środkowej i Wschodniej od X do XV w., red. W. Peltz, J. Dudck, Ziclona Góra 1997; D. Piwowarczyk, Obyczaj rycerski w Polsce późnośredniowiecznej (XIV-XV w.), Warszawa 1998. 
tucję Pokoju Bożego w X-XI wieku, na gruncie której doszło, choćby w ograniczonym zakresie, do współpracy pomiędzy Kościołem a częścią warstwy feudalnej.

Krokiem następnym, o zasadniczym znaczeniu, było ukształtowanie się w XI stuleciu idei „wojny świętej”, skierowanej przeciwko wrogowi zewnętrznemu, zagrażającemu (w rzeczywistości czy jedynie w propagandzie Kościoła) światu chrześcijańskiemu. Zapoczątkowana w toku wojen z Saracenami w Hiszpanii, idea ta „eksplodowała” krucjatami ${ }^{7}$. Do zagadnienia „wojny świętej” wypadnie jeszcze wrócić, na razie należy jednak powtórzyć, że aczkolwiek doświadczenia następnego dziesięciolecia na Bliskim Wschodzie uczynią z Bernarda z Clairvaux gorącego zwolennika i płomiennego propagatora II krucjaty, adresatem elogium w De laude novae militiae nie są, powtórzmy, wszyscy uczestnicy krucjat (cruciferi), owi milites Christi w szerszym slowa tego znaczeniu, lecz jedynie ich cząstka skupiająca się w młodych zakonach rycerskich, konkretnie templariusze.

\section{2.}

W grudniu 1144 roku, jak na ironię losu: w samo święto Bożego Narodzenia, wojska emira Mossulu i Aleppo zdobyły ważny strategicznie punkt oporu krzyżowców - Edessę. Była to pierwsza licząca się klęska zadana „Frankom” przez muzułmanów i nic dziwnego, że wywołała w Europie wielkie wrażenie, doprowadzając w konsekwencji do II krucjaty, która pod względem masowości przekroczyła nawet rozmiary pierwszej sprzed lat kilkudziesięciu. Rokjednak upłynął, zanim papież Eugeniusz III w odpowiedzi na wołania o pomoc chrześcijan na Wschodzie zdecydował się. bullą Quantum praedecessores wezwać na pomoc króla i rycerstwo francuskie. 1 marca 1146 roku została oficjalnie ogłoszona krucjata. Bernard z Clairvaux rozwinął ożywioną działalność na jej rzecz. Doszło, tak jak przy pierwszej krucjacie, do spontanicznych pogromów antyżydowskich we Flandrii i w Nadrenii. Po długich namowach Bernarda, 27 grudnia 1146 roku krzyż podjął (tak jak wcześniej Ludwik VII we Francji) król rzymski Konrad III. Wiadomo, że II wyprawa krzyżowa miała znacznie szerszy zasięg niż poprzednia: część krzyżowców uzyskała zgodę papieża na wyprawienie się przeciw muzułmanom na Półwyspie Pirenejskim; panowie sascy zaś, podnosząc, że byłoby mało celowe udawać się do Ziemi Świętej przeciw tak odległym "poganom” w sytuacji, gdy w bezpośrednim sąsiedztwie Saksonii, zaraz za Łabą, żyją i „srożą się” inni poganie - plemiona Słowian połabskich, woleli, także przy aprobacie papiestwa, wyprawić się przeciw temu przeciwnikowi ${ }^{8}$. W związku z Sejmem Rzeszy, jaki zebrał się w marcu 1147 roku we Frank-

7 Zob. odpowiednie partie monografii G. Minois, Kościót i wojna. Od czasów Biblii do ery atomowej, tł. A. Szymanowski, Warszawa 1998, rozdz. 5: Od pokoju Bożego do wojny świętej (XI-XIII w.); P. Contamine, Wojna w średniowieczu, tł. M. Czajka, Warszawa 1999, s. 279-289: Pokój i rozejm Boży, etyka rycerska, krucjata.

8 Tak zwana „krucjata słowiańska” 1147 roku ma już obszerną literaturę naukową, z której (szczególnie uwzględniając ideowe tło i rolę św. Bernarda) wymieniłbym na pierwszym miejscu ciąg świetnych, częściowo co prawda się powtarzających, ale także stalc pogłębiających problematykę prac Hansa-Dietricha Kahla: Zum Ergebnis des Wendenkreuzzuges von 1147, „Wichmann-Jahrbuch” 11-12, 1957-58, s. 99-120 (wyd. 2, w: Heidenmission und Kreuzzugsgedanke in der deutschen Ostpolitik des Mittelalters, red. H. Beumann, Darmstadt 1963, s. 275-316); Christianisierungsvorstellungen im Kreuzzugsprogramm Bemhards von Clairvaux. Anmerkungen zum geistesgeschichtlichen Kontext des "Wendenkreuzzugs” von 1147, „Przegląd Historyczny” 75,1984, s. 453-461; „...Auszujäten von der Erde die Feinde des Christennamens...”. 
furcie nad Menem, pozostaje godny uwagi i rzeczywiście wywolujący ożywioną kontrowersję naukową list Bernarda z Clairvaux, noszący w zbiorze epistolarnym tego autora numer $457^{9}$. Jest to apel do świata chrześcijańskiego (arcybiskupów, biskupów, książąt i wszystkich wiernych) o aktywny udział w przygotowywanej wyprawie krzyżowej. Nawiązując do słów psalmu 149,7, przedstawia Bernard tło i cel przedsięwzięcia: Bóg wzbudził w monarchach i książętach zapał do wzięcia pomsty na ludach pogańskich i do wypędzenia ich z ziem należących niegdyś i słusznie obecnie w sensie prawnym należących do chrześcijan (suscitaverit spiritum regum Deus et principum ad faciendam vindictam in nationibus et exstirpandas de terra christiani nominis). Łaska Boska zapewnia uczestnikom wyprawy wielkie korzyści. Nie uszło to uwagi szatana, zgrzyta on zębami i nie posiada się ze strapienia, że w ten sposób utraci niemal pewną zdobycz: dusze tych licznych grzeszników, które jemu — jak mniemał — się należą. Nawet ci najgorsi nawracają się, odwracają od złego i są gotowi czynić dobro.

Powyższe myśli występowały już we wcześniejszym ogólnym wezwaniu do wyprawy krzyżowej, teraz jednak dochodzi u Bernarda do głosu myśl nowa. Nawiązując do wersetów Listu św. Pawła do Rzymian (Rz 11,25 i n.), kontynnuje: Szatan boi się jeszcze czegoś, mianowicie nawrócenia pogan, „ponieważ słyszał, że przystąpią oni masowo [do wiary chrześcijańskiej] i cały Izrael zostanie zbawiony. Wydaje mu się, że nadszedł czas...".

List 457 Bernarda z Clairvaux nie zawiera wprawdzie ani jednej nazwy etnicznej, ale w sposób zupełnie pewny stwierdza, ojakich pogan tu chodzi: „nieprzyjaciele krzyża Chrystusowego, żyjący

Der Plan zum „Wendenkreuzzug” von 1147 als Umsetzung sibyllinischer Eschatologie, „Jahrbuch für dic Geschichte Mittelund Ostdeutschlands" 39,1990, s. 133-160; Die weltweite Bereinigungder Heidenfrage - ein übersehenes Kriegsziel des Zweiten Kreuzzugs, w: Spannungen und Widersprüche. Gedenkschrift für František Graus, Sigmaringen 1992, s. 63-89; Die Kreuzzugseschatologie Bernhards von Clairvaux und ihre missionsgeschichtliche Auswirkung, w: Bernhard von Clairvaux und der Beginn der Modeme, red. D. R. Bauer, G. Fuchs, 1996, s. 262-315. Poza tym: M. Unger, Bemhard ton Clairvaux und der Slawenkreuzzug 1147, „Zeitschrift für Geschichtswissenschaft” 7, 1959, s. 80-90; F. Lotter, Die Konzeption des Wendenkreuzzugs. Ideengeschichtliche, kirchenrechtliche und historisch-politische Voraussetzungen der Missionierung von Elb-und Ostseeslawen um die Mitte des 12. Jahrhunderts, Sigmaringen 1977 (Vorträge und Forschungen..., Sonderband 23); E.-D. Hehl, Kirche und Krieg im 12. Jahrhundert. Studien zu kanonischem Recht und politischer Wirklichkeit, Stuttgart 1980 (Monographicn zur Geschichte des Mittelalters, Bd. 19), rozdz. 5; H. O. Gaethke, Herzog Heinrich der Löwe und die Slawen nordöstlich der unteren Elbe, Frankfurt a. M. 1999, rozdz. 2;J. Trupinda, Krucjatowe poglądyśw. Bernarda z Clairvaux a ideologia Zakonu Krzyżackiego zawarta $w$ „Kronice” Piotra $z$ Dusburga, w: Cystersi w spoleczeństwie Europy Środkowej..., red. A. M. Wyrwa, J. Dobosz, Poznań 2000, s. 190-204 (zob. także monografię J. Trupindy wymienioną w przyp. 15). W tym kontekścic należy wspomnieć wcześniejszy, z 1108 roku, apel wschodniosaskich feudałów, nawołujacy do wyprawy zbrojnej (świętej wojny) przeciw pogańskim Słowianom połabskim, będący wczcsnym przejawem ducha krucjatowego i w sposób szczególny lączący element duchowy z zachętą materialną dla krzyżowców. Do wyprawy wówczas nie doszło. Zob.: M. Tangl, Der Aufruf der Bischöfe der Magdeburger Kirchenprovinz zur Hilfe gegen die Slawen aus dem Anfangdes 12. Jahrhunderts, „Neues Archiv der Gesellschaft für ältere deutsche Geschichtskunde” 30, 1905, s. 183-191; P. Knoch, Kreuzzug und Siedlung. Studien zum Aufruf der Magdeburger Kirche von 1108, "Jahrbuch für dic Geschichte Mittel- und Ostdeutschlands" 23, 1974, s. 1-33; G. Labuda, Wezwanie wschodniosaskich feudatów do walki ze Stourianami $z$ roku 1108, w: idem, Fragmenty dziejów Slowiańszczyzny zachodniej, t. 3, Poznań 1975, s. 233-269; G. Constable, The Place of the Magdeburg Charter of 1107/08 in the History of Eastern Germany and of the Crusades, w: Vita religiosa im Mittelalter. Festschrift fur Kaspar Elm zum 70. Geburtstag, red. F. J. Felten, N. Jaspert, współpr. S. Haarländer, Berlin 1999, s. 283-299; M. Dygo, Crusade and colonization: yet another response to the Magdeburg charter of 1108 AD, „Quacstiones Medii Aevi Novae" 6, 2001, s. 319-325.

${ }^{9}$ Zob. Sancti Bernardi opera, op. cit., t. 8, Romae 1977, s. 432 in. 
za Łabą" (hostes crucis Christi, qui sunt ultra Albi). Zresztą sprawę ostatecznie wyjaśnia wspomniana bulla papieża Eugeniusza III, gdzie krzyżowcy sascy mają wyprawić się „contra Sclavos ceterosque paganos habitantes versus aquilonem” („przeciw Słowianom i innym poganom żyjącym na północy”) ${ }^{10}$, oraz inne współczesne źródła.

Zbyt długo, nie omieszkał Bernard wytknąć, książęta chrześcijańscy, mimo swej potęgi, tolerowali niebezpieczne napady tych pogan. Teraz jednak nadszedł kres tych nieprawości. Ważne także, że wyprawa do Jerozolimy na tym nie ucierpi. Przeto po naradzie z królem, biskupami i książętami zebranymi we Frankfurcie wzywa Bernard siły chrześcijańskie, by odpowiednio wyposażone i uzbrojone podjęły krzyż, aby te pogańskie ludy albo zupełnie wyniszczyć, albo w sposób definitywny doprowadzić do chrztu (ad delendas penitus aut certe convertendas nationes illas).

W dalszym ciągu obiecuje Bernard wszystkim uczestnikom „wyprawy słowiańskiej” odpuszczenie grzechów takie samo, jakiego dostępują wyprawiający się do Ziemi Świętej, pod warunkiem, że będą posłuszni biskupom i książętom. Bernarda trapiła myśl, że względy na korzyści materialne moga przesłonić „krzyżowcom” prawdziwy cel wyprawy, dlatego surowo zabrania wchodzić w jakiekolwiek układy z poganami, czy to poparte pieniędzmi, czy przyrzeczeniem trybutu, „zanim z Boską pomocą albo sam kult pogański, albo ów naród nie zostanie zniszczony” (donec auxiliante Deo aut ritus ipse aut natio deleatur).

Te właśnie słowa („et ad delendas penitus aut certe convertendas nationes illas” oraz „donec [...] aut ritus ipse aut natio deleatur”) wywołały ożywioną dyskusję w nauce.

Eine solche Konzeption hatte vor 1147 theologisch wie kanonistisch als ungeheuerlich gegolten - zwraca uwagę Hans-Dietrich Kahl — wenn sie auch gelegentlich praktiziert worden war, zum Beispiel in den Judenpogromen der Frühphase des ersten Kreuzzugs, als Äußerung eines vulgären Frömmigkeitsfanatismus, den die offizielle Kirche niemals gebilligt hatte. Der von dieser Konzeption gespiegelte Standpunkt blieb auch weiterhin, was den Hauptstrom kirchlicher Geistes - und Rechtsgeschichte angeht, unrezipiert ${ }^{11}$,

choć co prawda sam Kahl potrafił przytoczyć poglądy odmienne, zbieżne z omawianym apelem Bernarda z Clairvaux.

„Zniszczyć” pogan, jeżeli nie ma widoków na ich nawrócenie... Pominiemy tutaj interesującą na swój sposób kwestię, czy Słowianie połabscy - a raczej to, co pozostało z ich politycznej organizacji i demograficznego potencjału - mogli rzeczywiście w polowie XII wieku poważniej zagrozić światu chrześcijan. Jak jednak tak wybitna umysłowość jak Bernard z Clairvaux, wielki autorytet moralny, „niekoronowany papież”, bodaj najwybitniejszy przedstawiciel zachodniego spirytualizmu, myśliciel głęboki, piewca duchowej, uwewnętrznionej miłości, uznany za Doktora Kościoła, mógł stawiać, nawet w czysto teoretycznym znaczeniu, taką nieludzką, chciałoby się powiedzieć, alternatywę przed pogańskimi Słowianami? Tym bardziej, że w innych sytuacjach,

\footnotetext{
${ }^{10}$ Tekst bulli papieskiej najłatwicj dostępny w: Pommersches Urkundenbuch, t. 1, wyd. 2, wyd. K. Conrad, Köln-Wien 1970, s. 37, nr 32.

${ }^{11}$ H.-D. Kahl, „...Auszujäten von der Erde..."..., op. cit., s. 137.
} 
na przykład w odniesieniu do Żydów, a nawet heretyków (albigensów), niejednokrotnie wydawał się reprezentować umiarkowane, raczej pojednawcze, a w każdym razie realistyczne stanowisko.

Podczas gdy znaczna część nauki historycznej, zwłaszcza konfesjonalnej-katolickiej, a już szczególnie cysterskiej, ale również na przykład Friedrich Lotter ${ }^{12}$, wiele wysiłku włożyła w próby osłabienia wymowy inkryminowanych cytatów Bernarda z Clairvaux, ostatecznie zrzucając winę na "ducha czasów”, ewentualnie na cechy osobowości Bernarda, Hans-Dietrich Kahl spróbował doszukać się klucza do wytłumaczenia gwałtowności i „niehumanitaryzmu” wielkiego cystersa w przejęciu się przezeń, wraz z wieloma nawet wybitnymi umysłami tej epoki, chiliastycznymi przepowiedniami i nastrojami, dla których upadek Edessy stanowił znakomitą pożywkę. Podobnie jak w innych okresach wzmożonego nawrotu podobnych nastrojów i oczekiwań (ostatnie z nich występowały około roku 1000 , a bodaj znacznie wyraźniej około 1033 roku) ${ }^{13}$, myśl o bezpośredniej bliskości Sądu narzucała co bardziej gorliwym misjonarzom wręcz obowiązek forsowania programu chrystianizacji niewiernych, jeżeli trzeba, to nawet poprzez skądinąd raczej przez Kościół odrzucany przymus bezpośredni (compellere intrare), co miało usprawiedliwiać „nadzwyczajne" środki ${ }^{14}$.

\section{3.}

Stosunek Kościoła katolickiego do wojen z „niewiernymi” to wielki, nie pozbawiony drażliwości, problem badawczy. Sytuuje się on w obrębie pokrewnych, znacznie szerszych problemów: stosunku do wojen w ogóle ${ }^{15}$ i stosunku do innowierców ${ }^{16}$. Nie sposób w niniejszym artykule pokusić się nawet o bardzo ogólne jego przedstawienie. Musi wystarczyć konstatacja, że problem ten przez całe właściwie dzieje chrześcijaństwa i Kościoła, zwłaszcza zachodniego, był kontrowersyjny, a stanowisko Kościoła, na które wielki wpływ wywarły zwłaszcza poglądy św. Augustyna, cechowała ambiwalencja. Pacyfizm najwcześniejszej fazy tej religii, mogący się zawsze powoływać na wyraźne wskazania Nowego Testamentu, został przezwyciężony stosunkowo szybko, w czym

12 Zob. F. Lotter, Die Konzeption des Wendenkreuzzugs..., op. cit.

${ }^{13}$ Z obszernej, także najnowszcj (wywołanej milenijną rocznicą) literatury na ten temat wymieniç jedynie: J. Fricd, Endzeiterwartungen um die Jahrtausendwende, „Dcutsches Archiv für Erforschung des Mittclaltcrs” 45, 1989, s. 381-473; S. Gouguenheim, Les fausses terreurs de l'an mil: attente de la fin des temps ou approfondissement du foi?, Paris 1999; R. Landes, The Fear of an Apocalyptic Year 1000: Augustinian Historiography, Medieval and Modern, „Speculum” 75, 2000, s. $97-145$. ${ }_{14}$ Zob. podstawowe dla tych spraw studium H.-D. Kahla, Die ersten Jahrhunderte der missionsgeschichtichen Mittelalters. Bausteine für eine Phänomenologie bis ca. 1050, w: Kirchengeschichte als Missionsgeschichte, t. 2: Die Kirche des frïhen Mittelalters, cz. 1, red. K. Schäferdiek, München 1978, s. 11-76.

15 Zob. prace cytowane w przyp. 7, oraz, na ograniczonym odcinku czasowym, pracę E. D. Hehla cytowaną w przyp. 8, a takżc: F. Prinz, Klerus und Krieg im früheren Mittelalter. Untersuchungen zur Rolle der Kirche beim Aufbau der Königsherrschaft, Stuttgart 1971 (Monographien zur Geschichte des Mittelalters, Bd. 2); R. Kottje, Die Tötung im Kriege. Ein moralisches und rechtliches Problem in frïhen Mittelalter, Barsbüttel 1991 (Beiträge zur Friedenscthik, H. 11); J. Trupinda, Ideologia krucjatow'a w' kronice Piotra z Dusburga, Gdańsk 1999, rozdz. 1: Stosunek zachodniego chrześcijaństu'a do wojny. Korclatcm wojny jest oczywiścic pokój, zob. pracę zbiorową Träger und Instrumentarien des Friedens im hohen und späten Mittelalter, red. J. Fried, Sigmaringen 1996 (Vorträge und Forschungen..., Bd. 43).

${ }^{16}$ Zob.: J. Lcclercq, Historia tolerancji w wieku reformacji, t\}. L. i H. Kühn, t. 1, ks. I, Warszawa 1964; L. Winowski, Innowiercy w pogladach uczonych zachodniego chrześijaństwa XIII-XIV w., Wrocław 1985 (zwł. rozdz. 5: Sprawa wojny' przeciw innowiercom); Toleranz im Mittelalter, red. A. Patschovsky, H. Zimmermann, Sigmaringen 1998 (Vorträge und Forschungen..., Bd. 45). 
z kolei dopomóc mogły liczne przykłady i „duch” Starego Testamentu, zwłaszcza gdy chrześcijaństwo w IV wieku stało się częścią rzymskiego establishmentu, tym bardziej zaś po upadku porządku rzymskiego, gdy w warunkach daleko idącego zamieszania i zaniku porządku państwowego doby wielkiej wędrówki ludów i najwcześniejszego średniowiecza Kościół niejednokrotnie bywał zmuszony do brania odpowiedzialności za społeczeństwo. Specyficzną formą tej odpowiedzialności była konieczność organizowania (lub uczestniczenia) odporu napadów ludów „zewnętrznych", najczęściej niechrześcijańskich (Hunowie, Awarowie, Węgrzy, Normanowie) lub heretyckich (większość ludów germańskich doby wielkiej wędrówki ludów); począwszy zaś od pierwszej połowy VIII wieku także ekspansywnego świata islamu. I chociaż pojęcie „wojny świętej” przed końcem wieku XI, to znaczy w okresie przedkrucjatowym, pojawiało się raczej sporadycznie, a wojny z niewiernymi we wczesnym średniowieczu traktowane były na ogół w „normalnych” kategoriach, nie różniących się zbytnio od wojen pomiędzy chrześcijanami (dobrym na to przykładem są wojny z muzułmanami na Półwyspie Pirenejskim), jednak zagrożenie (rzeczywiste czy wyimaginowane) ze strony innowierców sprzyjało postępującemu zaangażowaniu Kościoła, przybierającemu w okresie karolińskim i późniejszym postać bezpośredniego włączania się duchowieństwa w samą walkę. To ostatnie nie doczekało się co prawda jawnej aprobaty i było przez rozmaite środowiska duchowne nieraz otwarcie kontestowane, ale $z$ kolei sprzyjał mu rozwój stosunków lennych, nakładający zwłaszcza na biskupów i opatów obowiązek auxilium - służby zbrojnej. Kombinacja „zewnętrznych” i „wewnętrznych” okoliczności doszła bodaj do zenitu w monarchii ottońskiej; przykładów osobistego udziału kleru w wojnach i licznych ofiar życia wojowniczych przedstawicieli episkopatu jest bardzo wiele ${ }^{17} . \mathrm{Z}$ drugiej strony dopiero pod koniec wczesnego średniowiecza Kościół, uznając tym samym zasadność „wojny sprawiedliwej”, zrezygnował z dotąd obowiązującego nakazu pokuty za zabicie przeciwnika w wojnie. Jednego $z$ ostatnich, a zarazem najgłośniejszych przykładów tej pokuty dostarcza historia podboju Anglii przez Wilhelma Zdobywcę, akcji w końcu w pełni aprobowanej przez papieża - mimo to z woli arcybiskupa uczestniczący w niej Normanowie musieli się w kilka lat po roku 1066 poddać ciężkiej pokucie.

Aczkolwiek pacyfizm, odmawianie zasadności jakiejkolwiek wojnie, został dość skutecznie wyparty z nauki Kościoła i pojawial się co najwyżej na jego peryferiach oraz w niektórych ruchach uznanych za heretyckie, by dopiero w ostatnich dziesięcioleciach, zwłaszcza za pontyfikatu Jana Pawła II, do pewnego stopnia odzyskać znaczenie, pojawienie się hasła „wojny świętej” po sam koniec XI wieku stanowiło, także w odczuciu współczesnych, istotne i doniosłe w skutkach novum. Georges Minois ${ }^{18}$ zastanawia się, dlaczego świat chrześcijański dopiero po kilku stuleciach odpowiedzial tym hasłem na muzułmański jego odpowiednik — dzihad, dochodząc do wniosku, iż nie motywy religijne były tu decydujące, lecz pozareligijne, jak wolno się domyślać — zmieniające się wXI wieku w sposób dynamiczny ekonomiczno-społeczno-polityczne otoczenie Kościoła. „Eksplozja” wojowniczości Kościoła na zewnątrz, przeciw innowiercom, tym bardziej zasługuje na uwagę, że zarówno w tym właśnie

17 Zob.: F. Prinz, Klerus und Krieg..., op. cit.; L. Auer, Der Kriegsdienst des Klerus unter den sächsischen Kaiserm, „Mitteilungen des Instituts für Österreichische Geschichtsforschung” 79, 1971, s. 316-407; 80, 1972, s. 48-70.

${ }_{18}$ Zob. G. Minois, Kościót i wojna..., op. cit. 
okresie, jak i wcześniej (można powiedzieć, że wraz z rozkładem karolińskiego porządku w Europie i postępującego feudalizmu i partykularyzmu) tenże Kościół tak wiele uczynił dla ukrócenia anarchii wewnętrznej i ograniczenia wojen „pomiędzy chrześcijanami” ${ }^{19}$.

\section{4.}

W dalszym ciągu niniejszych uwag pragnę zatrzymać się na mniej znanym aspekcie wojen krzyżowych, mianowicie na formułowanych w świecie chrześcijańskim głosach krytycznych ${ }^{20}$. Musimy zdawać sobie sprawę z tego, że stanowiły one niejako nurt oboczny myśli chrześcijańskiej i że w warunkach przejęcia inicjatywy przez papiestwo oraz zarówno autentycznego, jak również umiejętnie i celowo podsycanego entuzjazmu, jaki na przestrzeni XI-XIII wieku niejednokrotnie ogarniał różne kręgi społeczeństwa europejskiego, miały one utrudnione możliwości ujawniania się i utrwalania. Występowały w różnych odmianach i natężeniu, posługiwały się różnymi argumentami, różny był też ich wpływ na współczesnych i różną uwagą je obdarzano w nowoczesnej nauce $^{21}$. Oczywiście, będziemy mogli wspomnieć jedynie kilka wypowiedzi tego rodzaju, lecz, jak sądzę, są one miarodajne i symptomatyczne.

Jak już wspomnieliśmy, opinie i głosy zdecydowanie krytyczne liczniej pojawiły się dopiero w związku z II krucjatą. Widać wyraźnie, że zwłaszcza postać i działalność Bernarda z Clairvaux bywała przedmiotem krytyki. Nie trzeba było, zdaniem niektórych krytyków, nawet wymieniać go $z$ imienia ${ }^{22}$. Nie wymienił Bernarda anonimowy rocznikarz z Turyngii, być może z klasztoru w Reinhardsbrunn koło Gothy, piszący według wszelkiego prawdopodobieństwa jeszcze przed 1150 rokiem, a zatem w bezpośrednim czasowym sąsiedztwie z wyprawą 1147 roku, którego dzieło zachowało się najlepiej w skompilowanej na początku XIII wieku kronice klasztoru św. Piotra w Erfurcie (Chronica S. Petri Erfordensis moderna) ${ }^{23}$. Pisze on, że królowie Konrad i Ludwik udali się do Jerozolimy, by z gorliwości religijnej (zelo fidei) walczyć z poganami, uczynili to zaś „zastraszeni i usidleni” (territi et circumventi) przez kazania „pewnych ludzi cieszących się wielką

19 Zob. podstawową w tej dzicdzinie monografię: H. Hoffmann, Gottesfriede und Treuga Dei, Stuttgart 1964 (Monumenta Germaniae Historica [dalcj: MGH], Schriften, Bd. 20).

${ }^{20}$ Zob.: P. A. Throop, Criticism of the Crusade. A Study of Public Opinion and Crusade Propaganda, Amsterdam 1940; G. Constable, The Second Crusade as Seen by Contemporaries, „Traditio” 9, 1953, s. 213-279; H. Glaser, Das Scheitern des zweiten Kreuzzugs als heilsgeschichtliches Ereignis, w: Festschrift Max Spindler, München 1969, s. 115-142; E. Sibcrry, Criticism of Crusading, 1095-1274, Oxford 1985.

${ }^{21}$ Zdecydowanie negatywny stosunck do krucjat miały ruchy heretyckie lub za takie uznane, zwł. albigensi, waldensi, lollardowic, husycj, franciszkańscy spirytuałowie. Z drugicj strony, co podnosi przede wszystkim Norman Housley, The Later Crusades, 1274-1580. From Lyon to Alcazar, Oxford 1992, s. 376 i n., występuje w nauce tendencja do absolutyzowania i wyolbrzymiania nastrojów i głosów antykrucjatowych takżc w okresic późnych krucjat. Krytycy konkretnych krucjat (na przykład John Wicliff, jeżeli chodzi o „krucjatę” biskupa Henryka Despenscra przeciw Flandrii, czy „nasz” Paweł Włodkowic w odniesieniu do rejz krzyżackich) na ogól nie dyskwalifikowali krucjat w ogóle, a nawet nickiedy je propagowali.

22 Do poniższego wywodu oprócz literatury wymicnionej w przyp. 20. zob. zwł. H.-D. Kahl, Die Kreuzzugseschatologie Bemhards von Clairvaux..., op. cit., s. 275 i n.

${ }^{23}$ Wyd. O. Holder-Egger, w: Monumenta Erphesfurtensia, Hannover-Leipzig 1899 (MGH, Scriptores rerum Germanicarum in usum scholarum [42]), s. $176 \mathrm{i} \mathrm{n}$. 
estymą i noszących szaty zakonne" (quorundam magne estimacionis et religiosi habitus hominum). Owi kaznodzieje, wykorzystując słowa apostoła Pawła (2 Tes 2,2), głosili, że „dzień Pański” jest tuż (quod instaret dies Domini, et cecitas ex parte in Israel contigit, donec multitudo gencium intraret, et sic ommis Israel salvus fieret). Widać jednak - to zdaje się nie ulegać wątpliwości z relacji rocznikarza turyngijskiego, mimo zamierzonego niedopowiedzenia - że nie była to dobra sprawa, skoro wyprawa zakończyła się sromotną klęską chrześcijan, król Konrad nie zdołał osiągnąć niczego korzystnego ani dla „pogan”, ani dla honoru imienia Niemców i godności cesarskiej.

Znacznie radykalniejsza krytyka sięgnęła duchowych ojców II wyprawy krzyżowej ze strony również anonimowego autora roczników z Würzburga (Annales Herbipolenses, anno 1147) ${ }^{24}$. Bóg doświadczył ciężko zachodnie chrześcijaństwo za grzechy ludzi. Pojawili się mianowicie „kłamliwi prorocy, synowie Beliala i świadkowie Antychrysta" (pseudoprophete, filii Belial, testes antichristi) i próżnymi słowy (inanibus verbis) uwiedli (seducerent) chrześcijan i cały ród ludzki próżnymi kazaniami przymusili (vana predicatione compellerent) do ruszenia w celu wyzwolenia Jerozolimy. Wpływ ich słów był tak niesłychany, że nie tylko prosty lud zbierał się składając zgodne śluby, lecz także królowie, książęta, margrabiowie i inni możni tego świata przekonani, że Bogu ofiarowuja służbę (obsequium se Deo prestare putantes), a nawet biskupi, arcybiskupi, opaci i pozostali słudzy i prałaci Kościoła przyłączali się do tej błędnej nauki (adiunctis in hunc ipsum errorem), popadając przez to w niewypowiedziane niebezpieczeństwo dla duszy i ciała. „Nic dziwnego, że -- nie wiem z jakiej ukrytej przyczyny — sam pan Eugeniusz, zajmujący Stolicę Rzymską, za sprawą Bernarda, opata z Clairvaux (innitente Clarevallensi abbate Bernhardo permotus)", rozesłał po całym świecie listy z obietnicą odpustu, które znalazły odpowiednie echo.

Interesujące świadectwo występowania w świeckich kręgach feudalnych swoistego sceptycyzmu wobec osoby i charyzmatu św. Bernarda zachowało się w Kronice Stowian Helmolda z Bozowa ${ }^{25}$, napisanej co prawda dopiero w latach sześćdziesiątych XII wieku, a zatem mniej więcej o jedno pokolenie młodszej od wydarzeń 1147 roku, ale w tym przypadku zasługującej na pełne zaufanie ze względu na osobę informatora. Osobą tą był bez wątpienia hrabia Adolf II z Schaumburga i Holsztynu, osoba bardzo zaangażowana w promocję ekspansji niemieckiej XII wieku na ziemie słowiańskie, przy tym - jako pierwotnie wychowywana do stanu duchownego (zob. Helmold I, 49) - niepozbawiona stosunkowo dobrego przygotowania intelektualnego i pozostająca $z$ wymienionym kronikarzem w bliskich stosunkach.

Rozdział 59 pierwszej księgi kroniki, zatytułowany O świętym Bermardzie, opacie z Clairvaux, rozpoczyna się następująco:

W owych to czasach zaszły nowe zdarzenia, które zdumiały cały świat (ortae sunt res novae et toti orbi stupendae). Za czasów pontyfikatu ojca świętego Eugeniusza, gdy sterem królestwa kierował Konrad III, zasłynął opat z Clairvaux Bernard.

\footnotetext{
${ }^{24}$ MGH Scriptores XVI, s. 3 i n.

${ }^{25}$ Dwujęzyczne (łacińsko-nicmicckic) wydanic H. Stooba: Helmold von Bosau, Slawenchronik, Darmstadt 1963; Helmolda Kronika Slowian, tł. J. Matuszewski, wyd. J. Strzclczyk, Warszawa 1974. Do tego zagadnicnia zob. H.-D. Kahl, Die Kreuzzugseschatologie Bernhards von Clairvaux..., op. cit., s. 284-289.
} 
Sława cudotwórcy przyciagała don tłumy ludzi „z całego świata”. Święty (Kahl podkreśla, że Helmold użył tego sformułowania, sanctus ille, jeszcze przed formalną kanonizacją Bernarda; ta nastąpiła dopiero w 1174 roku) przybył na „słynny sejm” do Frankfurtu, gdzie w obecności króla Konrada i dostojników zajmował się intensywnie uzdrawianiem tlumnie przybyłych chorych.

Wśród olbrzymiego thumu nie było wiadomo, na co kto cierpiał albo komu należało przyjść z pomocą. Był tam obecny również nasz hrabia Adolf, który pragnął dokładniej poznać wielkość męża wyrosłą za sprawą Bożą. Wówczas to przyprowadzono mu chłopca ślepego i kulawego, co do którego kalectwa nie mogło być żadnych wątpliwości. Wtedy bystry hrabia powziąl myśl, czyby nie poddać świętości Bernarda próbie, która by wykazała się na tym chłopcu. Spostrzegłszy jego niedowierzanie, jak gdyby za natchnieniem Boskim, mąż Boży poszukał na nie lekarstwa. Choć do innych tylko słowem się zwracał, wbrew zwyczajowi chłopca kazał do siebie przyprowadzić. Gdy zaś mu go podano, wziął go na ręce i przez dłuższe dotykanie przywrócił wzrok; następnie, wyprostowawszy mu zgięte kolano, kazał mu biec aż do stopni po to, by dać publicznie dowód odzyskania wzroku i możności ruchu.

Mamy zatem tu do czynienia niejako z wyzywaniem, przymuszaniem świętego do wykazywania nadprzyrodzonych mocy.

Ob Adolf wirklich ïberzengt wurde, berihhrt der Berichterstatter [Helmold] — bezeichnendenveise? - nicht -

— być może zbyt wiele usiłuje z tej historii wywnioskować Kahl, niemniej epizod powyższy wydaje się wskazywać na występowanie w 1147 roku opozycji, niekoniecznie tylko „świeckiej”, wobec działalności św. Bernarda. Następujące bezpośrednio potem obszerne przedstawienie wypraw zbrojnych do Ziemi Świętej i przeciw Słowianom połabskim, nieukrywające całkowitego chybienia celu, wydaje się wskazywać, że także kronikarz, aczkolwiek w bardzo zawoalowanej formie, do entuzjastów II wyprawy krzyżowej się nie zaliczał.

Zasługą niejednokrotnie już w niniejszym szkicu cytowanego uczonego niemieckiego Hansa-Dietricha Kahla jest zwrócenie uwagi na jeszcze jedno, niezmiernie cenne, świadectwo duchowej opozycji antykrucjatowej $^{26}$. Chodzi o tajemniczy, anonimowy (zdaniem Kahla autorem był zapewne benedyktyn z bawarskiego klasztoru Tegernsee) ${ }^{27}$, łacińskojęzyczny dramat, zwany w nauce najczęściej Ludus de Antichristo (zdaniem Kahla właściwszy byłby tytuł Liber de finibus saeculorum), powstały w postaci gotowej do przedstawienia prawdopodobnie w związku z pier-

\footnotetext{
${ }^{26} \mathrm{~W}$ dalszym ciągu opieram sic̨ na czçści swego artykułu pod tytułem $Z$ dziejów teorii i praktyki tolerancji w'średniouieczu. Trzy przykłady, w: Aetas media - aetas modema. Studia ofiarowane prof. Henrykoui Samsonowiczoui w' siedemdziesiąta rocznicę turodzin, Warszawa 2000, s. 583-585.

${ }_{27}$ Pełny tekst dramatu zachował się jedynic w rękopisic z Tegernsec, o którym zob. H. Plechl, Die Tegernseer Handschrift Clm 19411. Beschreibung und Inhalt, „Deutsches Archiv für Erforschung des Mittelalters” 18, 1962, s. 418-501.
} 
wszym ogólnoniemieckim zjazdem państwowym Fryderyka Barbarossy w Ratyzbonie w 1155 roku $^{28}$. Nieznany autor, „ein bemerkenswert unabhängiger, schöpferischer Geist”, „der mit seinem Traditionsgut fast unglaublich frei zu schalten wußte”, reprezentuje postawę procesarską („abendländisch-römische"), między innymi popiera koncepcję rozdziału władzy duchownej i świeckiej, odrzucenie pretensji francuskich $i$ bizantyjskich; jego utwór to jedyny w swoim rodzaju „pomnik średniowiecznej eschatologii i zarazem wczesnostaufijskiej krytyki aktualnych stosunków «sub specie aeternitatis»". Autor potępia zarówno wszelkie masowe ruchy ludowe i heretyckie, jak również wyprawy krzyżowe (właśnie: nie jedną konkretną, nieudaną wyprawę, lecz generalnie) i przymusowe nawracania, pogromy i wszelkie prześladowania religijne. Dozwolona jest jedynie obronna walka z zewnętrznymi poganami, zagrażającymi chrześcijanom. Potępienie wypraw krzyżowych — których Bóg nie chce! - stanowi oczywistą polemikę z Bernardem z Clairvaux i podobnie myślącymi zwolennikami „nowej szkoły” misyjnej. Choć Bernard, co zrozumiałe, nie występuje z imienia, stylizacja dramatu, jak choćby kłamliwe „cuda”, dokonywane przez Antychrysta przed oczyma króla niemieckiego, czy samo wydanie przezeń polecenie gwałtownej „misji” - wyprawy na niewiernych, stanowiące niedwuznaczne i niedwuznacznie chyba przez ówczesnych widzów czy słuchaczy odbierane aluzje do zgromadzeń w Spirze i Frankfurcie, na niego właśnie wskazują. „Sein [autora Ludus] Antichrist trägt in diesen Partien bernhardinische Züge"29.

${ }^{28}$ Zob. H.-D. Kahl, Der sog. „Ludus de Antichristo” (De Finibus Saeculorum) als Zeugnis frühstaufischer Gegenwartskritik. Ein Beitrag zur Geschichte der Humanität im abendländischen Mittelalter, „Mediaevistik. Internationale Zcitschrift für interdisziplinäre Mittelalterforschung" 4, 1991, s. 53-148; idem, Die Kreuzzugseschatologie Bernhards von Clairvaux..., op. cit., s. 311-315: Ein Antichrist mit bernhardinischen Zügen; zob. także zwięzły artykuł encyklopedyczny tcgoż autora w Lexikon des Mittelalters, t. 5, cz. 10, 1991, kol. 2169-2170. Dość obszerną literaturę na temat Ludus podaje A. Dąbrówka, Teatr $i$ sacrum $w$ średniowieczu. Religia-cywilizacja-estetyka, Wrocław 2001, s. 166-167, przyp. 321. Utwór był wielokrotnic wydawany drukiem, między innymi przez K. Langoscha, Geistliche Spiele. Lateinische Dramen des Mittelalters mit deutschen Versen, Darmstadt 1957, s. 179-230 (zob. s. 253-256 i 267-280) i G. Vollmann-Profe, Ludus de Antichristo, t. 1-2, Göppingen 1981 (to ostatnie wydanie uwzględnia później odkryte fragmenty).

${ }^{29}$ Pomijam tutaj bardzo dla epoki nietypowe, niezwykle dobitne w Ludus de Antichristo akcenty prożydowskie, przekonanie o konieczności bezwarunkowej tolerancji wobec judaizmu. Nicco o tym w mym artykule wskazanym w przyp. 26. 